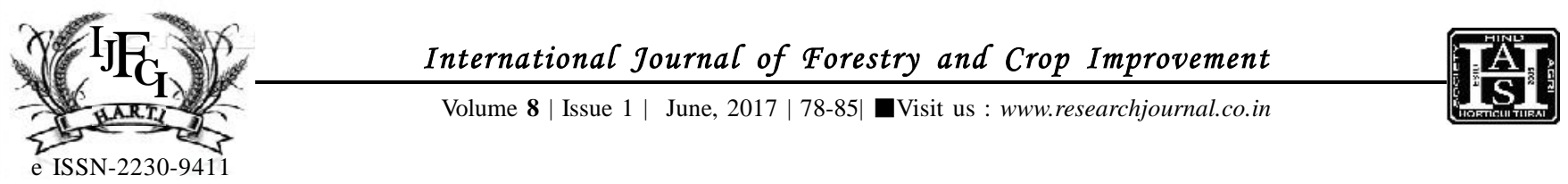

\title{
Traditional beekeeping for the restoration of degraded Agro ecosystem under Himalayan conditions of Jammu and Kashmir
}

\author{
MuneER AhMAd SOFIAND S.S. PATHANIA
}

\begin{abstract}
Jammu and Kashmir constitutes one of the most important bee-keeping zones in India. The three essential principles for the success of an industry viz., availability of raw material, skilled labor and consumer demand of the product are fully met within the state. Kashmir particularly is known for its floral gaieties where numerous varieties are cultivated and wild plants bloom from early spring till late fall. This provides sufficient raw material (nectar and pollen) to the honey bees, for the production of honey and bees wax for commercial purposes. This industry is of considerable national importance. It provides gainful employment to the thousands of rural families and can provide extra income to unemployed youth. It does not compete with agriculture but is complimentary to it. It does not require costly equipments tools. Tools used in this industry are fabricated locally and are within the reach of common man with little financial support. The honey bee habit of nesting in the dark enabled man to keep it in indigenously designed hives ranging from clay pots, boxes, logs, wall recesses of old houses inserted in Kashmir. One successful design for culturing Apis Cerana which was carried through generations and has become an ancestral heritage of villagers and beekeepers in almost all parts of Kashmir. Our state has plentiful bee flora in its natural endowment. The potential and success in beekeeping development is dependent on the quality and quantity of bees and bee flora available and the technology used. The necessary interventions are required at improving the efficiency and productivity of traditional methods, focusing on aspects of partial harvesting, such as leaving the brood-combs and taking only the honey comb.As per government census 2500 bee keepers registered with J\&K's Apiculture department. Kashmir have a potential to sustain one lakh bee colonies. On average, a colony produces 15 kilograms of honey and thus we have a potential to produce 15000 quintals of honey every year. Economic efficiency of Apis cerana (indigenous beekeeping) can prove more efficient then Apis mellifera and the local bees work in low temperatures as well so beekeeping with Apis cerana should be encouraged for rural households with low investment capacity.
\end{abstract}

KEY WORDS : Traditional beekeeping, Degraded, Ecosystem, Himalaya

How TO CITE THIS ARTICLE : Sofi, Muneer Ahmad and Pathania, S.S. (2017). Traditional beekeeping for the restoration of degraded Agro ecosystem under Himalayan conditions of Jammu and Kashmir. Internat. J. Forestry \& Crop Improv., 8 (1) : 78-85, DOI: 10.15740/HAS/ IJFCI/8.1/78-85.

\begin{tabular}{l}
\hline MEMBERS OF RESEARCH FORUM \\
Address of the Correspondence : MUNEER AHMAD SOFI, Division of \\
Entomology, Sher-e-Kashmir University of Agricultural Sciences and Technology of \\
Kashmir, Shalimar Campus, SRINAGAR (J\&K) INDIA Email: muneerento@yahoo.co.in \\
\hline Address of the Coopted Authors : S.S. PATHANIA, Division of Entomology, Sher- \\
e-Kashmir University of Agricultural Sciences and Technology of Kashmir, Shalimar \\
Campus, SRINAGAR (J\&K) INDIA
\end{tabular}

Article Chronical : Received : 02.03.2017; Accepted : 26.05.2017 